\title{
Holoptelea integrifolia (Roxb.) Planch: A Review of Its Ethnobotany, Pharmacology, and Phytochemistry
}

\author{
Showkat Ahmad Ganie and Surender Singh Yadav \\ Department of Botany, Maharshi Dayanand University, Rohtak, Haryana, India \\ Correspondence should be addressed to Surender Singh Yadav; ssyadavindia@rediffmail.com
}

Received 14 February 2014; Accepted 9 April 2014; Published 18 May 2014

Academic Editor: Ziad Daoud

Copyright ( 2014 S. A. Ganie and S. S. Yadav. This is an open access article distributed under the Creative Commons Attribution License, which permits unrestricted use, distribution, and reproduction in any medium, provided the original work is properly cited.

\begin{abstract}
Holoptelea integrifolia (Ulmaceae) is a versatile medicinal plant used in various indigenous systems of medicine for curing routine healthcare maladies. It is traditionally used in the treatment and prevention of several ailments like leprosy, inflammation, rickets, leucoderma, scabies, rheumatism, ringworm, eczema, malaria, intestinal cancer, and chronic wounds. In vitro and in vivo pharmacological investigations on crude extracts and isolated compounds showed antibacterial, antifungal, analgesic, antioxidant, anti-inflammatory, anthelmintic, antidiabetic, antidiarrhoeal, adaptogenic, anticancer, wound healing, hepatoprotective, larvicidal, antiemetic, CNS depressant, and hypolipidemic activities. Phytochemical analysis showed the presence of terpenoids, sterols, saponins, tannins, proteins, carbohydrates, alkaloids, phenols, flavonoids, glycosides, and quinines. Numerous compounds including Holoptelin-A, Holoptelin-B, friedlin, epifriedlin, $\beta$-amyrin, stigmasterol, $\beta$-sitosterol, 1, 4-napthalenedione, betulin, betulinic acid, hexacosanol, and octacosanol have been identified and isolated from the plant species. The results of several studies indicated that $H$. integrifolia may be used as an effective therapeutic remedy in the prevention and treatment of various ailments. However, further studies on chemical constituents and their mechanisms in exhibiting certain biological activities are needed. In addition, study on the toxicity of the crude extracts and the compounds isolated from this plant should be assessed to ensure their eligibility to be used as source of modern medicines.
\end{abstract}

\section{Introduction}

Plants have been rich source of medicinal agents since time immemorial. They have remained main components of various traditional systems of medicine, namely, Ayurveda, Unani, Siddha, Chinese, and so forth. Plant species has remained a good source of anti-infective agents, which are cost-effective and have fewer side effects [1]. Recently the WHO (World Health Organization) estimated that $80 \%$ of people worldwide rely on herbal medicines for some aspects. Many developing countries all over the world have intensified their efforts in documenting the ethnomedical data and scientific research on medicinal plants. It is estimated that there are 250,000 to 500,000 species of plants on earth [2]. There are about 47,000 plant species in India, out of which 7,500 plant species are of medicinal value; only 800 plant species are used in the preparation of herbal drugs. So, it is anticipated that plants can provide potential bioactive compounds for the development of new "leads" to combat various diseases. A vast proportion of the available higher plant species have not yet been screened for biologically active compounds; drug discovery from plants should remain an essential component in the search for new medicines. Herbal medicines have recently attracted much attention as alternative medicines useful for treating or preventing lifestyle-related disorders, but relatively very little knowledge is available about their mode of action. There has been a growing interest in the analysis of plant products which has stimulated intense research on their potential health benefits.

\section{Scope of Review}

The review of $H$. integrifolia was primarily needed to bridge the gaps in between traditional uses and in vitro pharmacological/biological studies. Previous reviews were based on 


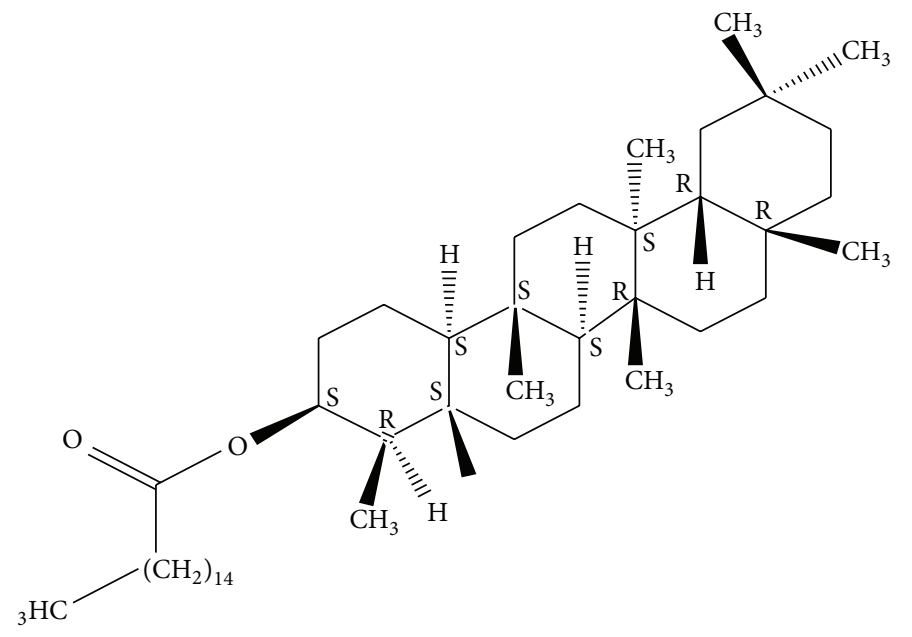

FIgURE 1: Holoptelin-A.

simple ethnobotanical uses and few pharmacological activities of the species. Hence, an attempt was made to update the complete information on botany, phytochemistry, and pharmacological activities of the species.

The information provided was taken from different sources like worldwide accepted scientific database Scopus (http://www.scopus.com), Science Direct (http://www.sciencedirect.com), PubMed (http://www.ncbi.nlm.nih.gov/ pubmed), Springerlink (http://www.springer.co.in), Google Scholar (http://scholar.google.co.in), and Wiley (http://www .onlinelibrary.wiley.com); thesis; recognized books; abstracts; conference proceedings; and nonimpact and nonindexed journals. The review highlighted the traditional uses of the species in Indian system of medicine (Table 2), secondary metabolites/phytoconstituents isolated from various parts of the plant (Figures 1-10) along with proven biological activity, different biological activities reported on various extracts, and fractions of different plant parts (Table 3 ). The traditional uses, reported biological/pharmacological activity, isolated compounds, and therapeutic application of $H$. integrifolia might be useful for scientists and researchers to find out new entities responsible for therapeutic activity.

\section{Botany}

3.1. Origin and Distribution. The plant species originated from Pacific Islands [3]. It is distributed in temperate and tropical areas of northern hemispheres. The plant is neutralized to the tropical regions of Asia including India, Nepal, Sri Lanka, Indo-China, Cambodia, Laos, Myanmar, Vietnam, Burma, and China [4]. In India it is found in outer Himalayan region from Jammu eastward up to $2000 \mathrm{ft}$. extending to Assam and Burma, and in southwards from Bengal to Central, Western and South India to dry region of Ceylon.

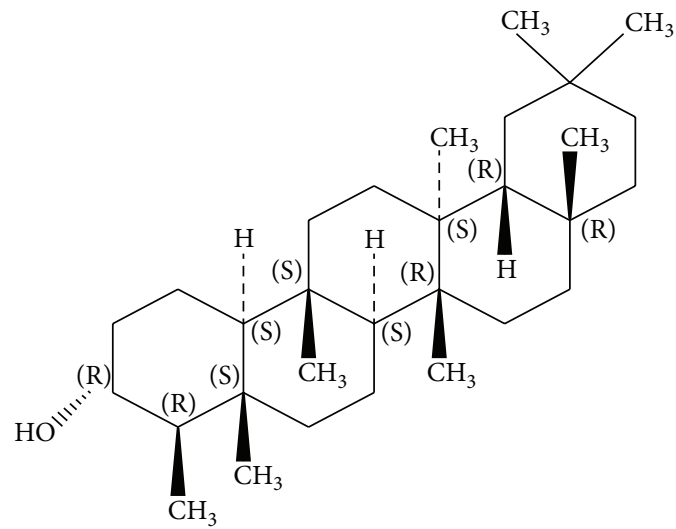

FIgURE 2: Holoptelin-B.

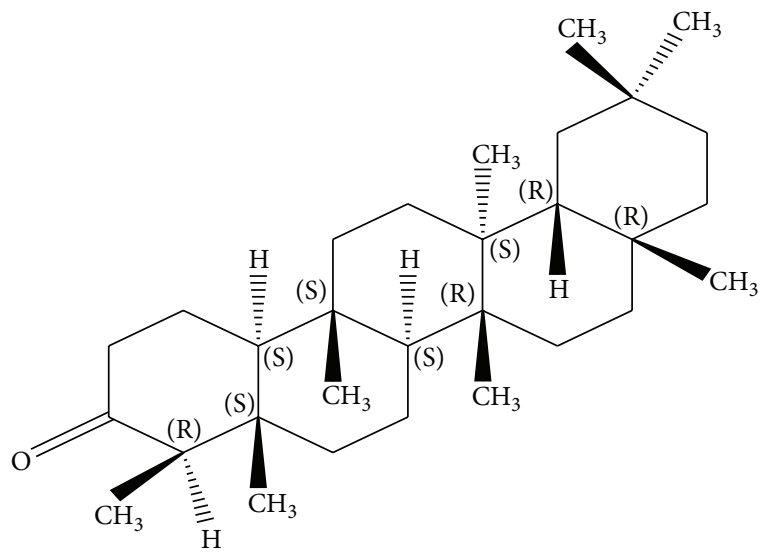

Figure 3: Friedlin.

\subsection{Taxonomic Status}

Domain: Eukaryota

Kingdom: Plantae

Division: Magnoliophyta 


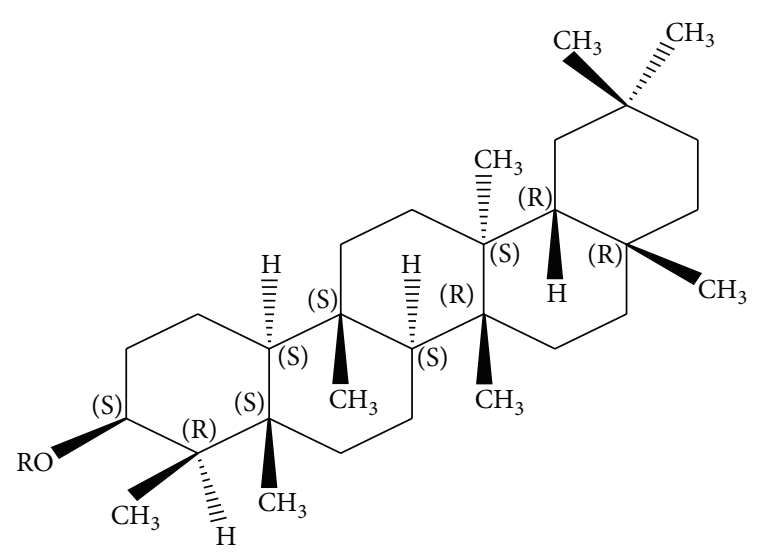

FIGURE 4: Epifriedlin.

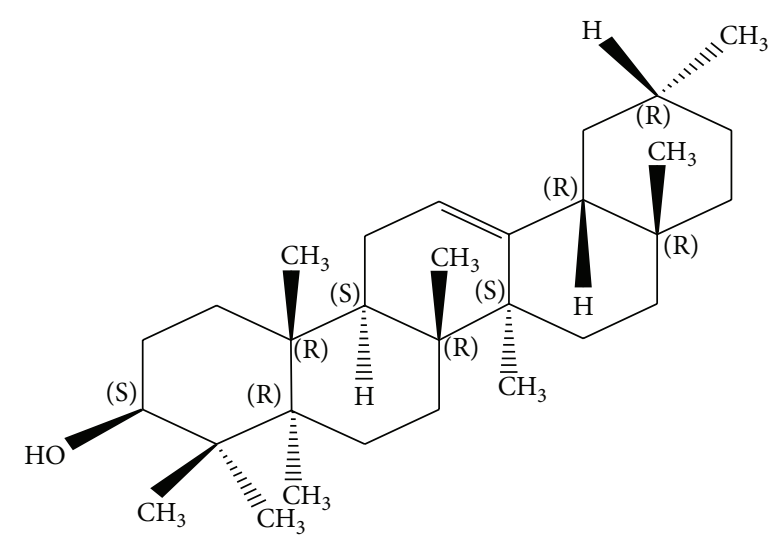

Figure 5: $\beta$-amyrin.

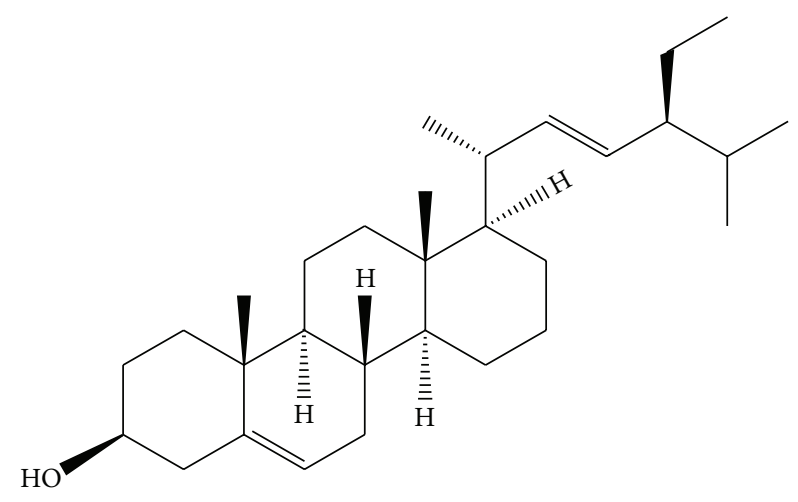

FiguRE 6: Stigmasterol.

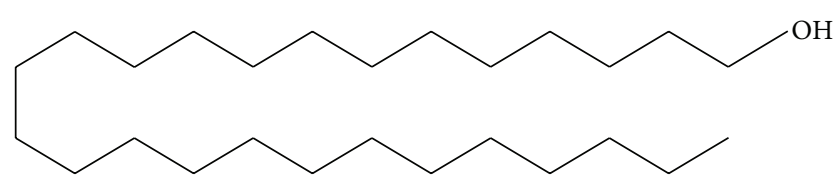

Figure 7: Hexacosanol.

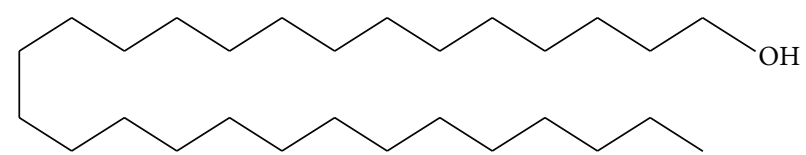

Figure 8: Octacosanol.<smiles>C=C(C)[C@@H]1CC[C@]2(C(=O)O)CC[C@]3(C)C(CCC4[C@@]5(C)CC[C@H](O)[C@](C)(CC)C5CC[C@]43C)C12</smiles><smiles>C=C(C)[C@H]1CC[C@]2(CO)CC[C@]3(C)C(CCC4[C@@]5(C)CC[C@@H](O)C(C)(C)C5CC[C@]43C)C12</smiles>

Figure 10: Betulin.
Class: Magnoliopsida
Order: Urticales
Family: Ulmaceae
Genus: Holoptelea
Species: integrifolia.

3.3. Plant Description. The plant is a large deciduous tree, up to $25 \mathrm{~m}$ high. Bark is $6-8 \mathrm{~mm}$ thick, whitish-grey, smooth with pubescent branchlets. Leaves are simple, alternate, stipulate, ovate or elliptic-ovate, and acuminate in shape. The bark when cut and leaves when crushed emit an unpleasant odor. Flowers are small, greenish-purple, and polygamous and found in short racemes or axillary fascicles. In male flowers, there are 8 stamens and in bisexual flowers 5 stamens are present. Ovary is superior, unilocular, compressed, and stalked. Style is very short (2.5-4 mm long) with bifid stigma. Fruits are one seeded samara, light brown, obliquely elliptic or orbicular, winged and stalked, indehiscent, and $2.5-3.5 \mathrm{~cm}$ long and $1.5-2.5 \mathrm{~cm}$ wide. Flowering and fruiting are seen 
TABLE 1: Vernacular names of Holoptelea integrifolia.

\begin{tabular}{|c|c|}
\hline Language & Vernacular name \\
\hline Hindi & $\begin{array}{l}\text { Papri, Chilbil, Kanju, Banchilla, Bawal, } \\
\text { Poothigam, Dhamna, Begana, Chirabil }\end{array}$ \\
\hline English & $\begin{array}{l}\text { Indian elm, Jungle cork tree, Monkey biscuit } \\
\text { tree, Indian beech tree }\end{array}$ \\
\hline Sanskrit & $\begin{array}{l}\text { Chirivilva, Pootikaranja, Udakirya, } \\
\text { Hasthivaruni, Markati, Vayasi, Karabhanji }\end{array}$ \\
\hline Malayalam & Aavil, Njettaval, Aval \\
\hline Punjabi & Rajain, Khulen, Arjan \\
\hline Telugu & Nemilinara, Nali, Thapasi, Nemali, Pedanevili \\
\hline Kannada & Kaladri, Nilavahi, Rahubija, Thavasai, Rasbija \\
\hline Tamil & Aya, Ayil, Kanci, Vellaya, Avil, Pattai \\
\hline Bengali & Nata karanja \\
\hline Marathi & Ainasadada, Vavala, Vavli, Papra, Bawal \\
\hline Oriya & Dhauranjan, Turuda, Karanja \\
\hline Gujarati & Charal, Charel, Kanjo, Waola, Chirbil, Chirmil \\
\hline Konkani & Vamvlo \\
\hline Burmese & Myaukseik, Pyaukseik \\
\hline Nepali & Sano pangro \\
\hline Siddha & Iya \\
\hline
\end{tabular}

during the months of February-March. Seeds are small, whitish, and kidney shaped.

3.4. Vernacular Names. Holoptelea integrifolia has many common names depending upon the languages spoken in a particular region. The names used in different languages are presented in Table 1.

3.5. Cultivation. The plant is commonly cultivated by the transplantation of nursery-raised seedlings. In the nursery, seedlings are raised by sowing seeds in lines about $12-20 \mathrm{~cm}$ apart. Transplantation is done when the seedlings are $10 \mathrm{~cm}$ in length at spacing of $22.5 \times 22.5 \mathrm{~cm}$. The seedlings are kept in the transplant beds for two years and then planted in the season of monsoon. Fresh seeds are also sown directly at the rate of 2 seeds per stake on the lines of $3 \mathrm{~m}$ apart. Continuous watering is required in both cases.

3.6. Diseases and Pests. Generally the plant is disease free; however, some pests attack it. Major pests of the tree are the tree borers of the groups Bostrichidae, Buprestidae, Cerambycidae, and Platypodidae, which commonly infest the stem and young leaves.

\section{Ethnomedicinal Uses}

The plant Holoptelea integrifolia is used traditionally for the treatment of inflammation, gastritis, dyspepsia, colic, intestinal worms, vomiting, wound healing, leprosy, diabetes, hemorrhoids, dysmenorrhea, and rheumatism [5]. Bark and leaves are used as bitter, astringent, thermogenic, anti-inflammatory, digestive, carminative, laxative, anthelmintic, depurative, repulsive, and urinary astringent [6]. Ethnomedicinally, the leaves and stem bark of $H$. integrifolia are used by tribal people for the treatment of various ailments (Table 2). The mucilaginous bark is boiled and the juice squeezed out and applied to rheumatic swellings [7]. Paste of the stem bark is externally applied to treat the inflammation of lymph glands, ringworm, and scabies. Decoction of the leaves is used to regulate fat metabolism, treat ringworm, eczema, and cutaneous diseases [8]. Stem bark acts as an anti-inflammatory agent specifically for eyes. Stem bark paste is externally applied on forehead of the patient suffering from common fever [9]. Bark and leaf paste of the plant are applied externally on the white patches or leucoderma. Bark boiled in coconut oil and mixed with garlic is applied externally to eczema [10]. For treatment of herpes simplex infection, bark paste is applied over the affected part until it disappears. Bark cut in the shape of a coin is tied on left arm below the shoulder for treatment of malaria [11]. It is also used for the treatment of intestinal cancer [12]. Leaf bud mixed with lime juice is applied externally to affected area for treatment of hair loss by infection [13]. Bark grounded with lemon juice and made into paste is used for weakness [14]. Seeds are used especially on ringworm and dried fruit in polyurea and urinary disorders [15].

\section{Pharmacology}

$H$. integrifolia is known to possess medicinal value in traditional system and represented a wide range of pharmacological properties. Even though several traditional uses of $H$. integrifolia are recognized, a scientific validity and supporting evidence are a prerequisite for commercial exploitation. Table 3 provides an overview on pharmacological properties of $H$. integrifolia extracts as well as compounds isolated from it. In the proceeding text some of the available reports pertaining towards the important pharmacological potential of $H$. integrifolia extracts are being discussed.

5.1. Antibacterial Activity. Vinod et al. [16] reported antibacterial effect of hexane, diethyl ether, acetone, and aqueous extracts of leaves of Holoptelea integrifolia against lactam resistant strain of Staphylococcus aureus. The diethyl ether extract has shown the highest activity and the active principle responsible for the present activity was found to be 1, 4naphthalenedione. The MIC of the compound was found to be $4 \mathrm{mg} / \mathrm{mL}$.

Padmaa and Durga [17] evaluated petroleum ether, benzene, chloroform, methanolic and aqueous extracts of stem bark of $H$. integrifolia for antibacterial activity against $S$. aureus, Bacillus subtilis, Escherichia coli, and Pseudomonas aeruginosa. Chloroform extract was found to be most effective against all the test microorganisms. The minimum inhibitory concentration for chloroform extract was found to be $25,50,100$, and $300 \mu \mathrm{g} / \mathrm{mL}$ against $B$. subtilis, $S$. aureus, $P$. aeruginosa, and $E$. coli, respectively.

In the following year, Ahmad et al. [18] studied antibacterial potential of chloroform leaf extract of Holoptelea integrifolia against various pathogenic microorganisms, namely, 
TABLE 2: Ethnomedicinal profile of Holoptelea integrifolia.

\begin{tabular}{|c|c|c|}
\hline Disease/disorder/indication & Part used/mode of application & Reference \\
\hline $\begin{array}{l}\text { Leprosy, boils, inflammation, skin disease, } \\
\text { and scorpion sting }\end{array}$ & Leaf is boiled in water and water bath is given & {$[39]$} \\
\hline Rickets & Young leaf is applied on back bone and tied for $1 \mathrm{hr}$. & {$[40]$} \\
\hline Headache & Bark is made into a paste and applied & {$[41]$} \\
\hline Chronic wound & Bark powder is applied & {$[42]$} \\
\hline $\begin{array}{l}\text { Leucoderma, leprosy, scabies, and other skin } \\
\text { diseases }\end{array}$ & Leaf and bark & {$[43]$} \\
\hline Uncontrolled bleeding, fresh wound & $\begin{array}{l}\text { Seeds are applied externally in the form of poultice } \\
\text { on the injured part }\end{array}$ & {$[44]$} \\
\hline Rheumatism & $\begin{array}{l}\text { Mucilaginous bark is boiled; juice is squeezed out } \\
\text { and applied to swellings }\end{array}$ & [7] \\
\hline Ringworm, eczema, and cutaneous diseases & Decoction of the leaves & {$[8]$} \\
\hline Common fever & Stem bark paste is externally applied on forehead & {$[9]$} \\
\hline Eczema & $\begin{array}{l}\text { Bark boiled in coconut oil and mixed with garlic is } \\
\text { applied }\end{array}$ & {$[10]$} \\
\hline Malaria & Bark cut and tied on an arm & {$[11]$} \\
\hline Intestinal cancer & Bark & {$[12]$} \\
\hline Herpes infection & $\begin{array}{l}\text { Leaf bud mixed with lime juice is applied externally } \\
\text { to affected area }\end{array}$ & {$[13]$} \\
\hline Weakness & $\begin{array}{l}\text { Bark grounded with lemon juice and made into paste } \\
\text { is given }\end{array}$ & {$[14]$} \\
\hline Polyurea and other urinary disorders & Dried fruit is used & {$[15]$} \\
\hline
\end{tabular}

Citrobacter freundii, Micrococcus luteus, Pseudomonas aeruginosa, and Pseudomonas fluorescence. The antibacterial sensitivity was analyzed using disk diffusion method at various concentrations where zone of inhibition was compared with the standard drug cefotaxime. The overall antibacterial activity of $H$. integrifolia was found to be strongest against $C$. freundii followed in descending order by $P$. fluorescence, $P$. aeruginosa, and $M$. luteus. The minimum inhibitory concentration (MIC) for chloroform leaf extract was found to be $1.562,3.125,3.125$, and $6.25 \mathrm{mg} / \mathrm{mL}$ against C. freundii, P. fluorescence, $P$. aeruginosa, and M. luteus, respectively. Another group, Joshi et al. [19], demonstrated antibacterial and antitubercular activity of $H$. integrifolia against different Gram-positive and Gram-negative bacterial strains and $M$. tuberculosis $\mathrm{H}_{37} \mathrm{RV}$ strain. Alcoholic extract showed moderate to good antibacterial and antitubercular activity.

5.2. Antifungal Activity. Besides antibacterial, $H$. integrifolia has a broad antifungal potential [20]. The alcoholic leaf and stem extracts of $H$. integrifolia were studied for antifungal activity against five fungal strains, namely, Candida tropicana, Candida krusei, Candida albicans, Aspergillus niger, and Saccharomyces cerevisiae using the agar well diffusion method. The results indicated that C. tropicana (MIC: $39 \mu \mathrm{g} / \mathrm{mL}$ ) is most sensitive to MSBE (methanolic stem bark extract) and S. cerviceae (MIC: $156.2 \mu \mathrm{g} / \mathrm{mL}$ ) and C. tropicana (MIC: $156.2 \mu \mathrm{g} / \mathrm{mL}$ ) is most and equal sensitive organisms to MLE (methanolic leaf extract). Their MICs ranged from 156.2 to
$1250 \mu \mathrm{g} / \mathrm{mL}$ and 39 to $625 \mu \mathrm{g} / \mathrm{mL}$ for MLE and MSBE, respectively. The lowest MMC (minimum microbicidal concentration) observed was $39.04 \mu \mathrm{g} / \mathrm{mL}$ for C. tropicana against MSBE.

Sahoo et al. [21] screened the different leaf extracts of Holoptelea integrifolia for antifungal activity against the test fungus Colletotrichum capsici. The hydroethanolic extract of leaves was fractionated by differential solubility method and only the petroleum ether extract was found to have fungitoxicity. MIC of the active fraction was worked out (200 ppm) and at this concentration it was fungicidal in nature. The active fraction, at MIC, was able to withstand heavy inoculum density, killed the test pathogen in $1.30 \mathrm{hrs}$. of exposure. It could be more effectively used at any $\mathrm{pH}$ between 4 and 9 and may prove to be superior to other commercial fungicides. The active fraction proved to be nonphytotoxic and it stimulated the rate of seed germination and seedling growth of Capsicum annuum seeds.

Ishnava et al. [22] evaluated different fractions of $H$. integrifolia leavesfor antifungal activity. The in vitro antifungal assay was performed by agar diffusion test and minimum inhibitory concentration (MIC) for hexane, ethyl acetate, and methanolic and aqueous fractions. Among these, ethyl acetate extract exhibited maximum antifungal activity against Alternaria sp., Aspergillus parasiticus, Aspergillus nidulans, Trichoderma harzianum, and Aspergillus flavus with MIC ranging from 80 to $40 \mathrm{ppm}$ against Aspergillus nidulans and Alternaria sp., respectively. 
TABLE 3: Pharmacological activities of various extracts of Holoptelea integrifolia.

\begin{tabular}{|c|c|c|c|c|}
\hline Activity & Plant part & Extract & Experimental procedures/models & References \\
\hline \multirow{3}{*}{ Antibacterial } & Leaves & $\begin{array}{l}\text { Hexane, diethyl ether, acetone } \\
\text { and aqueous }\end{array}$ & $\begin{array}{l}\text { MIC (minimum inhibitory } \\
\text { concentration) }\end{array}$ & {$[16]$} \\
\hline & Stem bark & $\begin{array}{l}\text { Pet. Ether, benzene, chloroform, } \\
\text { methanolic and aqueous }\end{array}$ & $\begin{array}{l}\text { MIC (minimum inhibitory } \\
\text { concentration) }\end{array}$ & {$[17]$} \\
\hline & Leaves & Chloroform & Disk diffusion assay & {$[18]$} \\
\hline \multirow{3}{*}{ Antifungal } & Leaf and stem & Methanolic & Agar well diffusion method & {$[20]$} \\
\hline & Leaves & Hydroethanolic & $\begin{array}{l}\text { MIC (minimum inhibitory } \\
\text { concentration) }\end{array}$ & {$[21]$} \\
\hline & Leaves & $\begin{array}{l}\text { Hexane, ethyl acetate, } \\
\text { methanolic, and aqueous }\end{array}$ & $\begin{array}{l}\text { Agar diffusion test and MIC } \\
\text { (minimum inhibitory } \\
\text { concentration) }\end{array}$ & {$[22]$} \\
\hline \multirow[b]{2}{*}{ Anti-inflammatory } & Leaves & Aqueous & $\begin{array}{l}\text { Carrageenan-induced paw } \\
\text { edema test }\end{array}$ & {$[23]$} \\
\hline & Leaves & Ethanolic & $\begin{array}{l}\text { Carrageenan-induced paw } \\
\text { edema, dextran-induced paw } \\
\text { edema, histamine-induced paw } \\
\text { edema, serotonin-induced paw } \\
\text { edema, and cotton } \\
\text { pellet-induced granuloma tests }\end{array}$ & {$[24]$} \\
\hline \multirow[t]{2}{*}{ Anthelmintic } & Stem bark & $\begin{array}{l}\text { Benzene, chloroform, } \\
\text { methanolic, aqueous, pet. ether }\end{array}$ & Dash's method & {$[25]$} \\
\hline & Bark & Ethanolic and aqueous & Time of paralysis and death assay & {$[26]$} \\
\hline \multirow{3}{*}{ Antioxidant } & Stem bark & Ethanolic & $\begin{array}{l}\text { FTC (ferric thiocyanate) and } \\
\text { TBA (thiobarbituric acid) } \\
\text { methods }\end{array}$ & {$[27]$} \\
\hline & Leaves & Methanolic & $\begin{array}{l}\text { 1,1,diphenyl-2-picrylhydrazyl } \\
\text { (DPPH) method }\end{array}$ & {$[20]$} \\
\hline & Stem bark & Aqueous & $\begin{array}{l}\text { DPPH radical, nitric oxide, } \\
\text { superoxide, and reducing power } \\
\text { assays }\end{array}$ & {$[28]$} \\
\hline \multirow[t]{2}{*}{ Antidiabetic } & Leaves & $\begin{array}{l}\text { Ethanolic, chloroform, pt. ether } \\
\text { and aqueous }\end{array}$ & Alloxan-induced diabetes model & {$[29]$} \\
\hline & Leaves & Methanolic and pet. ether & Alloxan-induced diabetes model & {$[30]$} \\
\hline Antidiarrhoeal & Leaves & Ethanolic & $\begin{array}{l}\text { Castor oil and magnesium } \\
\text { sulphate-induced diarrhea mice } \\
\text { model }\end{array}$ & {$[32]$} \\
\hline Adaptogenic & Stem bark & Ethanolic & $\begin{array}{l}\text { Forced swimming endurance test } \\
\text { and chronic cold restraint stress } \\
\text { mode }\end{array}$ & {$[34]$} \\
\hline \multirow{3}{*}{ Anticancer } & Leaves & Ethanolic & $\begin{array}{l}\text { Dolton's ascetic lymphoma } \\
\text { (DAL) model }\end{array}$ & {$[35]$} \\
\hline & Bark & Ethanolic and pet. ether & $\begin{array}{l}\text { DMBA- (dimethyl benz(a) } \\
\text { anthracene-) induced breast } \\
\text { carcinoma assay }\end{array}$ & {$[36]$} \\
\hline & Bark & $\begin{array}{l}\text { Butanol, hexane, ethyl acetate } \\
\text { and chloroform }\end{array}$ & $\begin{array}{l}\text { MTT 3-(4,5-dimethylthiazole- } \\
\text { 2yl)-2,5-biphenyl-tetrazolium } \\
\text { bromide assay }\end{array}$ & {$[37]$} \\
\hline Wound healing & $\begin{array}{c}\text { Stem bark and } \\
\text { leaves }\end{array}$ & Methanolic & $\begin{array}{l}\text { Excision and incision wound } \\
\text { model }\end{array}$ & {$[20]$} \\
\hline Antiulcer & Leaves & Methanolic & Pylorus ligated ulcer model & {$[45]$} \\
\hline Analgesic & Leaves & $\begin{array}{l}\text { Ethanolic, ethyl acetate, } \\
\text { n-butanol and aqueous }\end{array}$ & Tail flock method & {$[46]$} \\
\hline Hepatoprotective & Leaves & Methanolic & $\begin{array}{l}\text { Paracetamol-induced } \\
\text { hepatotoxicity assay }\end{array}$ & {$[47]$} \\
\hline
\end{tabular}


TABLE 3: Continued.

\begin{tabular}{lclll}
\hline Activity & Plant part & Extract & Experimental procedures/models & References \\
\hline Larvicidal & Leaves & Acetone & Standard WHO procedure & Cisplatin-induced nausea model \\
\hline Antiemetic & Leaves & Ethanolic & [48] & $\begin{array}{l}\text { Head dip, Rota rod, and traction } \\
\text { tests }\end{array}$ \\
\hline CNS depressant & Leaves & Methanolic & $\begin{array}{l}\text { HMG-CoA reductase and LCAT } \\
\text { (Lecithin: cholesterol-acyl } \\
\text { transferase) assays }\end{array}$ \\
\hline Hypolipidemic & Leaves and bark & Hydroalcoholic & [51] \\
\hline
\end{tabular}

5.3. Anti-Inflammatory Activity. Anti-inflammatory activity of $H$. integrifolia was reported by Sharma et al. [23]. The activity was analyzed by carrageenan- induced paw edema test in the male wistar strain rats, weighing between 150 and $200 \mathrm{gm}$. The aqueous extract of $H$. integrifolia, at doses 250 and $500 \mathrm{mg} / \mathrm{kg}$ was given to observe \% inhibition of paw edema which were comparable with indomethacin $(10 \mathrm{mg} / \mathrm{kg})$ used as a reference drug. The extract administered orally produced a significant $(P<0.05)$ dose-dependent inhibition of edema formation.

In another report, Kalpana and Upadhyay [24] investigated the anti-inflammatory properties of ethanolic extract of the leaves of Holoptelea integrifolia Planch. A dose of 250 and $500 \mathrm{mg} / \mathrm{kg}$ was given to observe percentage inhibition of paw edema which were comparable with indomethacin $(10 \mathrm{mg} / \mathrm{kg})$ used as a reference drug. The extract $(500 \mathrm{mg} / \mathrm{kg})$ exhibited maximum anti-inflammatory effect (30.01, 21.72, 32.34 , and $29.62 \%$ ) with carrageenan, dextran, histamine, and serotonin method, respectively. A significant percentage inhibition of paw edema by the extract as compared to standard drug suggests its usefulness in acute and chronic anti-inflammatory models.

5.4. Antihelminthic Activity. Anthelmintics or antihelminthics are drugs that expel parasitic worms (helminths) from the body, by either stunning or killing them. They may also be called vermifuges (stunning) or vermicides (killing). The first report on antihelminthic activity of $H$. integrifolia was provided by Nadella and Paarakh [25]. The activity of different stem bark extracts was evaluated against Pheretima posthuma. Among all the extracts tested, methanolic and aqueous extracts showed better and dose-dependent activity in comparison with reference standard piperazine citrate. Methanolic extract at $80 \mathrm{mg} / \mathrm{mL}$ showed shortest time of paralysis (9.0 $\pm 0.89 \mathrm{~min}$.) and death $(35.66 \pm 0.81 \mathrm{~min}$. $)$ when compared to piperazine citrate ( 33.4 and $55.6 \mathrm{~min}$., resp., at $60 \mathrm{mg} / \mathrm{mL}$ ).

In another study, Kaur et al. [26] comparatively studied the anthelmintic potential of ethanolic and aqueous extract of $H$. integrifolia bark using Eisenia fetida. In the bioassay, time of paralysis $(P)$ and time of death $(D)$ of the worms were determined at various concentrations $(10,25,50$, and $100 \mathrm{mg} / \mathrm{mL})$. The bioassay revealed that the ethanolic and aqueous extract significantly demonstrated paralysis and also caused death of worms especially at higher concentration. The ethanolic extract showed shortest time of paralysis $(6.26 \pm 0.08 \mathrm{~min}$.$) and death (16.73 \pm 0.21 \mathrm{~min}$. $)$ at $100 \mathrm{mg} / \mathrm{mL}$. The results were comparable with standard piperazine citrate $(2.95 \pm 0.09 \& 7.10 \pm 0.11 \mathrm{~min}$., resp., at $10 \mathrm{mg} / \mathrm{mL})$.

5.5. Antioxidant Activity. An antioxidant is a molecule that can terminate chain reactions by removing free radical intermediates and inhibit other oxidation reactions. Holoptelea integrifolia possess antioxidants which are responsible for the scavenging activity through various mechanisms. In one study, Saraswathy et al. [27] screened ethanolic crude extract of stem bark of Holoptelea integrifolia for its antioxidant activity using $\alpha$-tocopherol as standard antioxidant. The free radical scavenging activity of the extract was evaluated by two different methods, ferric thiocyanate and thiobarbituric acid methods at a concentration of $0.02 \%$ and compared with vitamin E. In FTC method, the control showed highest absorbance value (0.83), followed by extract (0.29), standard vitamin $\mathrm{E}(0.28)$ on day 5; however, in TBA method, the control had the highest absorbance value (0.35), followed by H. integrifolia (0.08) and Vitamin E (0.075). Thus ethanolic extract exhibited significant in vitro antioxidant activity by inhibiting the oxidation of linoleic acid in both FTC and TBA methods.

In another study, the methanolic extract of leaves (MLE) and stem bark (MSBE) of $H$. integrifolia was screened for antioxidant activity by 1,1-diphenyl-2-picrylhydrazyl (DPPH) using HPLC method, and total phenolic content was also estimated. MSBE was found to be most potent antioxidant and had more phenolic content than the MLE. The higher phenolic content of MSBE might have contributed to higher antioxidant activity of MSBE [20].

Recently, Srivastava et al. [28] evaluated the in vitro antioxidant potentials and phenolic content of aqueous extract of $H$. integrifolia stem bark. The activity was determined by different methods, namely, DPPH radical, nitric oxide, superoxide, and reducing power assays. The DPPH radical scavenging activity ranged from 13.14 to $55.17 \%$, comparable to standard ascorbic acid (22.56-93.68\%). The IC ${ }_{50}$ value of plant extract for scavenging free radicals was $77.10,74.95$, and $86.78 \mu \mathrm{g} / \mathrm{mL}$ by $\mathrm{DPPH}$, nitric oxide, and superoxide assays, respectively. The total phenolic content was found to be $61.73 \pm 0.23 \mathrm{mg} \mathrm{GAE} / \mathrm{g}$.

5.6. Antidiabetic Activity. Mamatha [29] studied the effect of different extracts, namely, ethanolic, petroleum ether, 
aqueous, and chloroform of Holoptelea integrifolia leaves for their antidiabetic activity by using alloxan-induced diabetes models using albino rats. The study indicated that ethanolic, chloroform, and aqueous extracts had more significant $(P<$ $0.01)$ antidiabetic activity $(178.3 \pm 2.916,192.7 \pm 4.09$, and $195.0 \pm 2.89$, resp.) in acute as well as prolonged treatment $(162.7 \pm 1.47,172.9 \pm 5.05$, and $180.9 \pm 2.28$, resp.) compared to control $(210.7 \pm 3.24)$. The results were comparable with reference standard glibenclamide (170.18 $\pm 2.58,159.8 \pm 2.53)$. Petroleum ether extract did not show significant $(P<0.05)$ activity at 7 th hour in acute study $(207.7 \pm 4.42)$ compared to diabetic control.

Sharma et al. [30] screened methanolic and petroleum ether extract of leaves of $H$. integrifolia for antidiabetic activity. Diabetes in the test animal (male wistar albino rat) was induced by a toxic glucose analogue, Alloxan. The activity was compared with a standardglibenclamide. The petroleum ether extract at 100 and $200 \mathrm{mg} / \mathrm{kg}$ and methanolic extract at $200 \mathrm{mg} / \mathrm{kg}$ concentration showed significant antidiabetic activity. The activity may be due to presence of steroids and glycosides in the test extracts. These phytocompounds may cause inhibition of ATP-sensitive potassium channels in pancreatic beta cells. This inhibition causes cell membrane depolarization, which causes voltage-dependent calcium channels to open and increase in intracellular calcium in the beta cells which stimulates insulin release.

Recently, Sharma et al. [31] studied antidiabetic activity of stem bark extract of $H$. integrifolia in alloxan-induced diabetic rats. The treatment was continued for three weeks to estimate blood glucose level, body weight, and lipid profile. The blood glucose level decreased gradually in the animals treated with the bark extract (250 and $500 \mathrm{mg} / \mathrm{kg}$ b.w.) orally. The prevention of loss of body weight in diabetic animals was found to be significant on day 15 in the animals of both treatment groups.

5.7. Antidiarrhoeal Activity. Report on antidiarrheal potential of Holoptelea integrifolia was provided by Shrinivas et al. [32]. The ethanolic leaf extract of $H$. integrifolia was studied against diarrhea in mice induced by castor oil and magnesium sulphate. In the experiment, the test extract, at the doses of 250 and $500 \mathrm{mg} / \mathrm{kg}$, reduced the total number of faeces as well as the total number of diarrhoeic faeces in a dosedependent manner. On the other hand, in the gastrointestinal motility test, the extract at the same doses retarded significantly $(P<0.01)$ the intestinal transit of charcoal meal in mice when compared to the control, atropine sulphate (5 mg/kg).

5.8. Adaptogenic Activity. Adaptogens or adaptogenic substances are a new class of metabolic regulators which increases the ability of an organism to adapt to environmental factors and to avoid damage from such factors [33].

Many herbs have been reported to possess adaptogenic agents. $H$. integrifolia is one such a plant which has adaptogenic activity. Kumar et al. [34] reported the adaptogenic activity of ethanolic stem bark extract of $H$. integrifolia in comparison with Withania somnifera. The activity was analysed in female albino Wister rats, using forced swimming endurance test and chronic cold restraint stress mode at doses of 250 and $500 \mathrm{mg} / \mathrm{kg}$. Both the doses of test extract were able to increase the swimming endurance when compared with animals who received normal saline.

5.9. Anticancer Activity. The effect of Holoptelea integrifolia on dalton's ascitic lymphoma in Swiss albino mice was reported by Lakshmi et al. [35]. The ethanolic extract of leaves of $H$. integrifolia has been tested for anticancer activity at the dose of 250 and $500 \mathrm{mg} / \mathrm{kg}$ b.w. The study was conducted to determine the effect of EHI on tumour volume, tumour cell count, viable tumour cell count, mean survival time, and increase in life span. The findings of the study suggested that the crude extract of test plant has potential anticancer activity. The extract increased the life span of DAL treated mice and restored the hematological parameters as compared with the DAL bearing mice in a dose-dependent manner. Soujanya et al. [36] observed anti-breast cancer activity of ethanolic extract of $H$. integrifolia Planch against 7,12dimethyl benz(a)anthracene induced breast carcinoma in experimental rats. In the study body weight of experimental animals, tumor burden, tumor multiplicity, and tumor volume of breast were determined. The extract administered orally at doses of 250 and $500 \mathrm{mg} / \mathrm{kg}$ showed significant $(P<0.05,0.01)$ dose-dependent inhibition of breast cancer formation. The tumor multiplicity was found to be 1 per group. \% inhibition of breast cancer formation by the test extract was almost the same as shown by standard drug tamoxifen.

Recently, Guo et al. [37] observed antineoplastic (anticancer/antitumor) activity of butanol, hexane, ethyl acetate, and chloroform bark extracts of Holoptelea integrifolia. The effect was studied on small cell lung cancer, breast, prostate, and colorectal and hepatocellular cancer cell lines. The findings of the study showed that hexane and ethyl acetate extracts had significant cytotoxic effects on breast and prostate cancer cells. Interestingly, hexane extract was selectively over approx. 2-fold more toxic in prostate cancer cells, 2.5-fold in colon cancer cells, and 5-fold in breast cancer cells. Similarly, ethyl acetate extract was selectively approx. 2- to 3-fold more toxic in all the cancer cells compared to non-cancer HEK293 cells. Specifically, the $\mathrm{IC}_{50}$ value of only $29.77 \pm 1.17 \mathrm{mg} / \mathrm{mL}$ of ethyl acetate in prostate cancer cells was over 3-fold highly toxic than HEK293.

5.10. Wound Healing Activity. Wound healing is a complex phenomenon, including proliferation of both parenchymal and connective tissue cells, synthesis of ECM (extracellular matrix proteins), remodeling of connective tissue and parenchymal components, and acquisition of wound strength [38].

The wound healing potential of $H$. integrifolia was observed by Reddy et al. [20]. In the study, two different extracts of $H$. integrifolia, namely, methanolic leaf (ML) and methanolic stem bark (MSB) extracts, were analyzed for wound healing potential in albino rats using two wound models, excision wound model, and incision wound model. The 
findings revealed that, in excision wound model, more than $90 \%$ wound healing was recorded in treated groups by 14 days of post-surgery, whereas only $62.99 \%$ was observed in the control group. In incision model, higher breaking strengths and higher hydroxyproline content in treated groups suggested higher collagen redeposition than the control group. Besides, the external application of these extracts on the wound prevented the microbes from invading the wound, resulting in the protection of wound against the microbial infections.

5.11. Antiulcer Activity. Peptic ulcer disease (PUD) is a serious gastrointestinal disorder that requires a well-targeted therapeutic strategy. Hemamalini et al. [45] reported the antiulcer activity of $H$. integrifolia leaves. The activity of test extract was evaluated using pylorus ligated ulcer model in rats and compared with the standard omeprazole. The methanolic extract at $500 \mathrm{mg} / \mathrm{kg}$ per oral dose significantly $(P<0.01)$ reduced the ulcer index $(3.43+0.06)$, ulcer formation $(69.61 \%)$, volume of gastric juice $(3.85+0.08 \mathrm{~mL})$, free acidity $(34.67+0.88 \mathrm{Eq} / \mathrm{L})$, and total acidity $(69.17+$ $1.01 \mathrm{Eq} / \mathrm{L}$ ) in pylorus ligation-induced ulcer models in rats. The ulcer curative ratio of methanolic extract was almost comparable to that of standard.

5.12. Analgesic Activity. An analgesic (informally known as painkiller) is any member of the diverse group of drugs used to relieve pain and to achieve analgesia.

Various medicinal herbs have been reported to have analgesic potential. However, the first study towards the analgesic activity of Holoptelea integrifolia was observed by Rizwani et al. [46]. In the study different fractions of $H$. Integrifolia leaves were evaluated for analgesic activity in mice by tail flick method. At the dose of $500 \mathrm{mg} / \mathrm{kg}$ the test extracts were found to have a significant $(P<0.05)$ analgesic activity when compared to standard diclofenac sodium $(50 \mathrm{mg} / \mathrm{kg})$. Maximum effect was established at $150 \mathrm{~min}$, after drug administration. The maximum analgesic activity was shown by ethanolic extract and followed in descending order by ethyl acetate, $n$-butanol, and aqueous extract.

5.13. Hepatoprotective Activity. Hepatoprotection or antihepatotoxicity is the ability to prevent damage to the liver. Recently, Hemamalini and Sathya [47] reported the hepatoprotective activity of methanolic extracts of Holoptelea integrifolia against $\mathrm{CCl}_{4}$ induced hepatotoxicity. In the study, effect of test extract at a dose of $500 \mathrm{mg} / \mathrm{kg}$ on the levels of serum marker enzymes Alanine Transaminase (ALT), Aspartate Transaminase (AST), Alkaline Phosphatase (ALP), and Total Bilirubin (TB) was determined. The study showed that methanolic extract $(500 \mathrm{mg} / \mathrm{kg})$ exhibited a significant protective effect by altering the serum levels of AST, ALT, ALP, and total bilirubin. These observations were supported by histopathological studies. Simultaneous treatment of methanolic extracts of $\mathrm{H}$. integrifolia with $\mathrm{CCl}_{4}$ showed less damage to the hepatic cells as compared to the rats treated with $\mathrm{CCl}_{4}$ alone. Histological changes such as steatosis (fatty change, fatty degeneration, or adipose degeneration), inflammatory infiltrations, and perivenular fibrosis were observed in $\mathrm{CCl}_{4}$ treated (toxic) control group. The test extract prevented these histological changes, further indicating its hepatoprotective activity.

5.14. Mosquito Larvicidal Activity. The first study related to larvicidal activity of Holoptelea integrifolia was reported by Singha et al. [48]. The effect of acetone extract from $H$. integrifolia leaves was evaluated on larval mortality of Culex vishnui after 24,48 , and $72 \mathrm{~h}$ of exposure with five concentrations of crude extract $(0.1,0.2,0.3,0.4$, and $0.5 \%)$. The study showed that the mortality rate of all larval instars at $0.5 \%$ concentration was significantly higher $(P<0.05)$ than at $0.1,0.2,0.3$, and $0.4 \%$ concentrations. Highest mortality was observed at $400 \mathrm{ppm}$ concentration of acetone extract. Higher mortality rate was also recorded in $72 \mathrm{~h}$ bioassay than those in 24 and $48 \mathrm{~h}$. The results of regression analysis revealed that the mortality rate $(Y)$ was positively correlated with the period of exposure $(X)$. The log probit analysis (95\% confidence level) revealed that $\mathrm{LC}_{50}$ values gradually decreased with the exposure period.

5.15. Antiemetic Activity. An antiemetic is a drug that is effective against vomiting and nausea. Effect of ethanolic extract of leaves of $H$. integrifolia on cisplatin-induced nausea using a rat model was investigated for antiemetic activity by Shrinivas et al. [49]. Cisplatin at $3 \mathrm{mg} / \mathrm{kg}$ dose was selected for testing the antinausea activity of extract. Cisplatin-induced pica decreased significantly when animals were pretreated with $H$. integrifolia extract at doses of 250 and $500 \mathrm{mg} / \mathrm{kg}$.

5.16. CNS Depressant Activity. Hemamalini et al. [50]observed the CNS (central nervous system) depressant activity of the methanolic leaf extract of Holoptelea integrifolia in Swiss albino mice. A daily dose of $250 \mathrm{mg} / \mathrm{kg}$ of extract was administered to the animals for 15 days, after which various CNS experiments such as exploratory behavior and muscle relaxant were recorded and compared with the control animals. The findings revealed that the test extract caused significant reduction in exploratory behavioral pattern in head dip test and reduction in muscle relaxant activity in rota rod and traction tests. These findings confirmed the CNS depressant activity in tested animal models.

5.17. Hypolipidemic Activity. Hypolipidemic or antihyperlipidemic agents are lipid-lowering drugs that are used in the treatment of hyperlipidemias. The leaf and bark paste of Holoptelea integrifolia is traditionally used for the treatment of obesity in Asian countries. Based on the fact Subhash and Augustine [51] investigated the hypolipidemic effect of $H$. integrifolia and its mechanism in diet-induced obese rat model. In the study body weight, serum lipids, and lecithin: cholesterolacyltransferase (LCAT), apolipoproteins, HMG-CoA reductase, and faecal fat content, were estimated after oral administration. The findings of the study showed that the test extract markedly lowered body weight, serum lipids, HMGR activity, and apo B and increase high-density lipoprotein-cholesterol and apo A1 concentrations. The faecal 
TABLE 4: Qualitative phytochemical screening of Holoptelea integrifolia.

\begin{tabular}{|c|c|c|c|c|c|c|c|c|c|c|c|}
\hline Solvent & Plant part & Reducing sugar & Protein & Phenol & Alkaloid & Steroid & Triterpenoid & Flavones & Tannin & Saponins & Reference \\
\hline \multirow{2}{*}{ Pt. Ether } & Leaf & + & + & - & - & + & - & + & + & - & \\
\hline & Stem & - & - & - & - & + & - & - & + & - & \\
\hline \multirow{2}{*}{ Benzene } & Leaf & - & - & - & - & + & - & + & + & - & \\
\hline & Stem & - & + & - & - & + & - & + & + & - & \\
\hline \multirow{2}{*}{ Chloroform } & Leaf & - & + & - & - & + & - & - & - & - & {$[8]$} \\
\hline & Stem & - & + & + & - & + & - & + & - & - & \\
\hline \multirow{2}{*}{ Methanol } & Leaf & - & + & - & + & + & - & - & - & - & \\
\hline & Stem & - & + & + & + & + & + & + & + & - & \\
\hline \multirow{2}{*}{ D. Water } & Leaf & - & - & + & - & - & + & - & + & - & \\
\hline & Stem & - & - & - & - & - & + & - & + & - & \\
\hline Acetone & Leaf & + & + & + & + & + & - & + & + & + & [18] \\
\hline
\end{tabular}

$(+)$ : present and (-): absent.

analysis showed a remarkable increase in faecal lipids, which indicates the ability to inhibit intestinal fat absorption. Presence of a compound 3-(7-ethoxy-4-methyl-2-oxo-2Hchromen-3-yl) propanoate $(\mathrm{Cl})$ in the test extract could be responsible for the present activity, which might have inhibited HMGR activity and block intestinal fat absorption.

\section{Phytochemistry}

Holoptelea integrifolia, the versatile medicinal plant, is the unique source of various types of compounds having diverse chemical structure. The plant species contains wide range of phytochemicals such as terpenoids, sterols, saponins, tannins, proteins, carbohydrates, and alkaloids [18, 52]. In addition $H$. integrifolia also contains flavonoids, phenols, cardiac glycosides, coumarins, and quinines [53]. The qualitative phytochemical screening of $H$. integrifolia is presented in Table 4. Many compounds were isolated from the plant and proven to be biologically active. Holoptelin-A (Figure 1), Holoptelin-B (Figure 2), friedlin (Figure 3), epifriedlin (Figure 4), 2 -aminonaphthoquinone, $\beta$-sitosterol, $\beta$-D-glucose, $\beta$-amyrin (Figure 5 ), stigmasterol (Figure 6 ), and hederagenin have been isolated from heart wood and bark while hexacosanol (Figure 7), octacosanol (Figure 8), $\beta$-sitosterol, and $\alpha$-amyrin were isolated from leaves [28]. Sadasivan et al. [16] isolated an antibacterial compound 1, 4-naphthalenedione from diethyl ether leaf extract of $H$. integrifolia. Recently, Ahmad et al. [54] isolated two medicinal pentacyclic triterpenoids, betulinic acid (3 $\beta$-Hydroxy- lup-20(29)-en-28-oic acid) (Figure 9), and betulin (Lup-20(29)-ene-3 $\beta$, 28-diol) (Figure 10) from methanolic bark extract. These isolated compounds were identified as betulinic acid and botulin, respectively, on the basis of detailed spectroscopic analysis and their comparisons with the data reported in the chemical literature for these components. The distinguishable position in 13C-NMR of betulin was found at C-17 $=47.8 \mathrm{ppm}$ and C-28 $=60.8 \& 60.6$ whereas in the betulinic acid the value of the same carbon signals depicted in the spectrum was at $56.3 \& 56.26$ and $180.5 \& 179.62$ due to the attachment of $\mathrm{CH}_{2} \mathrm{OH}$ and $\mathrm{COOH}$, respectively. Betulinic acid has valuable biological potential, such as inhibitors of HIV-1 entry, HIVprotease, or of reverse transcriptase (RT), whereas betulin had significant anticancer effect on adenocarcinoma, cervix carcinoma, hepatoma, and breast cancer.

\section{Conclusion}

It is evident from the available literature that Holoptelea integrifolia leaves are the most investigated part of the plant. Leaf and stem bark has been a promising agent for the treatment of skin diseases like leucoderma, scabies, ringworm, and eczema. The biological studies such as antimicrobial, antihelminthic, antidiabetic, anti-inflammatory, and antioxidant activities were noticeable in crude extracts of various parts of the plant. In parallel to above observations pure compound 1, 4-napthalenedione was marked for antibacterial activity against $\beta$-lactam resistant strain of Staphylococcus aureus. The detailed study of pharmacology, bioassay guided isolation of active principles, and mechanism of action may help to understand the relation between pharmacological effects and traditional uses of $H$. integrifolia. There are many areas to work in this plant for its full recognition. Factors such as geographical and seasonal variation play an important role in the authentication of the chemical constituents responsible for the activity which also can be an area of interest. Thus, it is mandatory to fill the huge gap of insufficient knowledge and awareness among pharmacologists as well as researchers to hold the position of this plant in providing better medicinal values to the society. This can be fulfilled only by generating interest among research community through writing reviews and carrying out research on different aspects of this plant species.

\section{Conflict of Interests}

The authors declare that there is no conflict of interests regarding the publication of this paper. 


\section{Acknowledgment}

Financial assistance from University Grants Commission, New Delhi, and Haryana State council for Science and Technology (HSCST), Department of Science and Technology, Government of Haryana is thankfully acknowledged.

\section{References}

[1] S. H. Samsam and F. Moatar, Natural Medicines and Plants, Mashal Publications, Tehran, Iran, 1991.

[2] R. P. Borris, "Natural products research: perspectives from a major pharmaceutical company," Journal of Ethnopharmacology, vol. 51, no. 1-3, pp. 29-38, 1996.

[3] A. Singh, "Exotic floristic diversity of the Varanasi district of Uttar Pradesh, India," Indian Journal of Plant Sciences, vol. 1, pp. 73-84, 2012.

[4] V. D. Bambhole and G. G. Jiddewar, "Antiobesity effect of Iris versicolor and Holoptelea integrifolia in rats," Sachitra Ayurveda, vol. 37, pp. 557-561, 1985.

[5] P. K. Warrier, V. P. K. Nambiar, and C. Ramakutty, Indian Medicinal Plants: A Compendium of 500 Species, Orient Longman, 1995.

[6] N. D. Prajapati, S. S. Purohit, and A. K. Sharma, A Handbook of Medicinal Plants: A Complete Source Book, Agrobias, Jodhpur, India, 2003.

[7] K. M. Nandkani, Indian Materia Medica, Popular Prakashan, Mumbai, India, 1976.

[8] J. K. P. Benjamin and P. K. S. Christopher, "Preliminary phytochemical and pharmacognostic studies of Holoptelea integrifolia Roxb," Ethnobotanical Leaflets, vol. 13, pp. 1222-1231, 2009.

[9] V. K. Singh and Z. A. Ali, "Folk medicines in primary health care: common plants used for the treatment of fevers in India," Fitoterapia, vol. 65, no. 1, pp. 68-74, 1994.

[10] V. H. Harsha, S. S. Hebbar, V. Shripathi, and G. R. Hegde, "Ethnomedicobotany of Uttara Kannada district in Karnataka, India plants in treatment of skin diseases," Journal of Ethnopharmacology, vol. 84, no. 1, pp. 37-40, 2003.

[11] P. Mahishi, B. H. Srinivasa, and M. B. Shivanna, "Medicinal plant wealth of local communities in some villages in Shimoga district of Karnataka, India," Journal of Ethnopharmacology, vol. 98, no. 3, pp. 307-312, 2005.

[12] J. G. Graham, M. L. Quinn, D. S. Fabricant, and N. R. Farnsworth, "Plants used against cancer-an extension of the work of Jonathan Hartwell," Journal of Ethnopharmacology, vol. 73, no. 3, pp. 347-377, 2000.

[13] M. Parinitham, G. U. Harish, N. C. Vivek, T. Mahesh, and M. B. Shivanna, "Ethnobotanical wealth of Bhadra wild life sanctuary in Karnataka," Indian Journal of Traditional Knowledge, vol. 3, pp. 37-50, 2004.

[14] N. Rajakumar and M. B. Shivanna, "Ethno-medicinal application of plants in the eastern region of Shimoga district, Karnataka, India," Journal of Ethnopharmacology, vol. 126, no. 1, pp. 64-73, 2009.

[15] C. P. Khare, Indian Medicinal Plants: An Illustrated Dictionary, Spinger Science, 2007.

[16] N. V. Vinod, M. Haridas, and C. Sadasivan, "Isolation of 1,4naphthalenedione, an antibacterial principle from the leaves of Holoptelea integrifolia and its activity against $\beta$-lactam resistant Staphylococcus aureus," Indian Journal of Biochemistry and Biophysics, vol. 47, no. 1, pp. 53-55, 2010.
[17] P. Padmaa and N. Durga, "Antibacterial activity of different extracts of stem bark of Holoptelea integrifolia," International Research Journal of Pharmacy, vol. 2, pp. 111-113, 2011.

[18] S. Ahmad, R. Sharma, S. Mahajan, R. Agnihotri, and A. Gupta, "Antibacterial evaluation and preliminary phytochemical analysis of the leaf extract of Holoptelea integrifolia," Journal of Pharmacy Research, vol. 5, pp. 3823-3825, 2012.

[19] S. D. Joshi, C. S. Hallikeri, and V. H. Kulkarni, "Evaluation of antibacterial and antitubercular activities of Holoptelea integrifolia (Roxb) Planch bark," Universal Journal of Pharmacy, vol. 02, pp. 87-90, 2013.

[20] B. S. Reddy, R. K. K. Reddy, V. G. M. Naidu et al., "Evaluation of antimicrobial, antioxidant and wound-healing potentials of Holoptelea integrifolia," Journal of Ethnopharmacology, vol. 115, no. 2, pp. 249-256, 2008.

[21] K. K. Sahoo, V. K. Yadav, and A. R. Saxena, "Antifungal properties of Holoptelea integrifolia (Roxb.) Planch," Annals of Plant Protection Sciences, vol. 18, pp. 438-442, 2010.

[22] K. B. Ishnava, K. H. Chauhan, and C. A. Bhatt, "Screening of antifungal activity of various plant leaves extracts from Indian plants," Archives of Phytopathology and Plant Protection, vol. 45, no. 2, pp. 152-160, 2012.

[23] S. Sharma, K. Lakshmi, A. Patidar, A. Chaudhary, and S. Dhaker, "Studies on anti-inflammatory effect of aqueous extract of leaves of Holoptelea integrifolia, Planch. in rats," Indian Journal of Pharmacology, vol. 41, no. 2, pp. 87-88, 2009.

[24] Kalpana and A. Upadhyay, "Anti-inflammatory evaluation of ethanolic extract of leaves of Holoptelea integrifolia Planch," Scholars Research Library, vol. 1, no. 2, pp. 185-195, 2010.

[25] D. Nadella and P. M. Paarakh, "Evaluation of anthelmintic activity of Holoptelea integrifolia (Roxb.) Planch," International Journal of Research in Ayurveda and Pharmacy, vol. 1, pp. 637641, 2011.

[26] S. Kaur, B. Kumar, S. Puri, P. Tiwari, and K. Divakar, "Comparative study of anthelmintic activity of aqueous and ethanolic extract of bark of Holoptelea integrifolia," International Journal of Drug Development and Research, vol. 2, no. 4, pp. 758-763, 2010.

[27] A. Saraswathy, D. S. Nandini, and D. Ramasamy, "Antioxidant, heavy metals and elemental analysis of Holoptelea integrifolia Planch," Indian Journal of Pharmaceutical Sciences, vol. 70, no. 5, pp. 683-686, 2008.

[28] J. Srivastava, K. N. Dwivedi, and H. P. Pandey, "Assessment of antioxidant activity and total phenolic content of aqueous stem bark extract of Holoptelea integrifolia Planch," International Journal of Pharmacy and Pharmaceutical Sciences, vol. 5, pp. 357-361, 2013.

[29] M. K. Mamatha, Phytochemical investigation and antidiabetic activity of Holoptelea integrifolia Planch [M.S. thesis], KLE University, Karnataka, India, 2009.

[30] S. Sharma, P. Khatri, A. Pandey, V. Jakhetia, L. Chaturvedi, and N. Dwivedi, "Anti-diabetic screening of leaves extract of Holoptelea integrifolia Roxb," International Journal of Pharmaceutical Research and Development, vol. 2, pp. 66-71, 2010.

[31] J. Sharma, S. C. Sharma, Y. S. Sarangdevot, and B. Vyas, "Study of antidiabetic activity of the stem bark extract of Holoptelea integrifolia (Roxb.)," Research Journal of Pharmacology and Pharmacodynamics, vol. 4, pp. 181-184, 2012.

[32] S. Shrinivas, K. S. Lakshmi, and T. Rajesh, "Evaluation of antidiarrhoeal potentials of ethanolic extract of leaves of Holoptelea integrifolia in mice model," International Journal of Pharmaceutical Research, vol. 1, no. 3, pp. 832-836, 2009. 
[33] A. Panossian, G. Wikman, and H. Wagner, "Plant adaptogens III. Earlier and more recent aspects and concepts on their mode of action," Phytomedicine, vol. 6, no. 4, pp. 287-300, 1999.

[34] B. Kumar, S. Puri, J. Debnath, M. Salhan, M. kaur, and A. Mittal, "Comparative pharmacological evaluation of adaptogenic activity of Holoptelea integrifolia and Withania somnifera," International Journal of Drug Development and Research, vol. 3, no. 1, pp. 84-98, 2011.

[35] K. S. Lakshmi, S. S. Sharma, T. Rajesh, and V. Chitra, "Antitumour activity of ethanolic extract of leaves of Holoptelea integrifolia on Dalton/s ascitic lymphoma in Swiss albino mice," International Journal of Green Pharmacy, vol. 4, no. 1, pp. 44-47, 2010.

[36] J. Soujanya, P. Silambujanaki, and V. Leela Krishna, "Anticancer efficacy of Holoptelea integrifolia, Planch. against 7, 12-dimethyl benz(a)anthracene induced breast carcinoma in experimental rats," International Journal of Pharmacy and Pharmaceutical Sciences, vol. 3, no. 5, pp. 103-106, 2011.

[37] H. Guo, D. S. Wang, G. H. Rizwani et al., "Antineoplastic activity of Holoptelea integrifolia (Roxb.) Planch bark extracts (in vitro)," Pakistan Journal of Pharmaceutical Sciences, vol. 26, pp. 11511156, 2013.

[38] S. C. Ramzi, K. Vinay, and R. Stanley, Pathologic Basis of Diseases, WB Saunders, Philadelphia, Pa, USA, 1994.

[39] K. K. Khanna, V. Mudgal, G. Shukla, and P. K. Shrivastav, "Unreported ethnomedicinal uses of plants from Mirazapur district, Uttar Pradesh," in Ethnobotany in South Asia, J. K. Mahalakshmi, Ed., Scientific Publishers, Jodhpur, India, 1996.

[40] K. K. Singh and A. Prakash, "Observation on ethnobotany of Kol tribe of Varanasi district, Uttar Pradesh," in Ethnobotany in South Asia, J. K. Mahalakshmi, Ed., Scientific Publishers, Jodhpur, India, 1996.

[41] D. K. Mishra, G. Somanta, and T. K. Mishra, "Ethnomedicine of the tribe Kharia of Midnapore district, West Bengal," in Ethnobotany in South Asia, J. K. Mahalakshmi, Ed., Scientific Publishers, Jodhpur, India, 1996.

[42] S. Pawar and D. A. Patil, "Ethnomedicinal uses of barks in Jalgaon district," Natural Product Radiance, vol. 6, no. 4, pp. 341346, 2007.

[43] H. Singh, Medicinal Plants and Their Local Uses in SubHimalayan Tract of Uttaranchal, Medicinal Plants: Ethnobotanical Approach, Agrobios, Jodhpur, India, 2006, edited by P. C. Trivedi.

[44] M. J. Beg, M. Z. Beg, and S. J. Ali, Ethnomedicinal Studies on Sub-Himalayan Forest of North Eastern Utter Pradesh in Medicinal Plants: Ethnobotanical Approach, Agrobios, Jodhpur, India, 2006, edited by P. C. Trivedi.

[45] K. Hemamalini, S. Suvidha, A. Bhargav, and U. Vasireddy, "Evaluation of anti-ulcer activity of methanolic extracts of Kigelia africana, Sophara interrupta and Holoptelea integrifolia leaves in experimental rats," International Journal of Current Pharmaceutical Research, vol. 4, pp. 16-21, 2012.

[46] G. H. Rizwani, S. Mahmud, H. Shareef, R. Perveen, and M. Ahmed, "Analgesic activity of various extracts of Holoptelea integrifolia (Roxb) Planch leaves," Pakistan Journal of Pharmaceutical Sciences, vol. 25, pp. 629-632, 2012.

[47] K. Hemamalini and S. B. Sathya, "Hepatoprotective activity of Sophara interrupta and Holoptelea integrifolia against carbontetrachloride induced hepatotoxicity in rats," International Journal of Biology Pharmacy and Allied Sciences, vol. 2, pp. 8089, 2013.
[48] S. Singha, U. Adhikari, A. Ghosh, and G. Chandra, "Mosquito larvicidal potentiality of Holoptelea integrifolia leaf extract against Japanese Encephalitis Vector, Culex vishuni," Journal of Mosquito Research, vol. 2, pp. 25-31, 2012.

[49] S. Shrinivas, K. Ravindra, M. Aradhana, and B. Kailash, "Ethanolic leaf extract of Holoptelea integrifolia Planch. decreases cisplatin-induced pica in rats," Journal of Pharmacognosy, vol. 7, no. 16, pp. 293-297, 2008.

[50] K. Hemamalini, L. G. Soujanya, U. Vasireedy, and P. Pavani, "CNS activity of the methanolic leaf extracts of Sophora interrupta Bedd, Kigelia pinnata Dc, Holoptelea integrifolia plants in experimental animal models," International Journal of Pharmacy and Technology, vol. 3, pp. 3785-3791, 2011.

[51] A. K. Subhash and A. Augustine, "Hypolipidaemic effects of methanolic extract of Holoptelea integrifolia (Roxb.) Planchon bark in diet-induced obese rats," Applied Biochemistry and Biotechnology, vol. 169, no. 2, pp. 546-553, 2013.

[52] S. Mahmud, H. Shareef, M. Ahmad, S. Gouhar, and G. H. Rizwani, "Pharmacognostic studies on fresh mature leaves of Holoptelea integrifolia (ROXB) Planch," Pakistan Journal of Botany, vol. 42, no. 6, pp. 3705-3708, 2010.

[53] S. R. Kumar, C. Venkateshwar, G. Samuel, and R. S. Gangadhar, "Phytochemical screening of some compounds from leaf extracts of Holoptelea integrifolia (Planch.) and Celestrus emarginata (Grah.) used by Gondu tribes at Adilabad district, Andhra Pradesh, India," International Journal of Engineering Science Invention, vol. 2, pp. 65-70, 2013.

[54] M. Ahmed, G. H. Rizwani, F. V. Mohammed, I. Mahmood, V. U. Ahmed, and S. Mahmud, "Triterpenoid antioxidant agents found in Holoptelea integrifolia (Roxb) Planch," International Journal of Pharmaceutical, Chemical and Biological Science, vol. 3, pp. 63-67, 2013. 

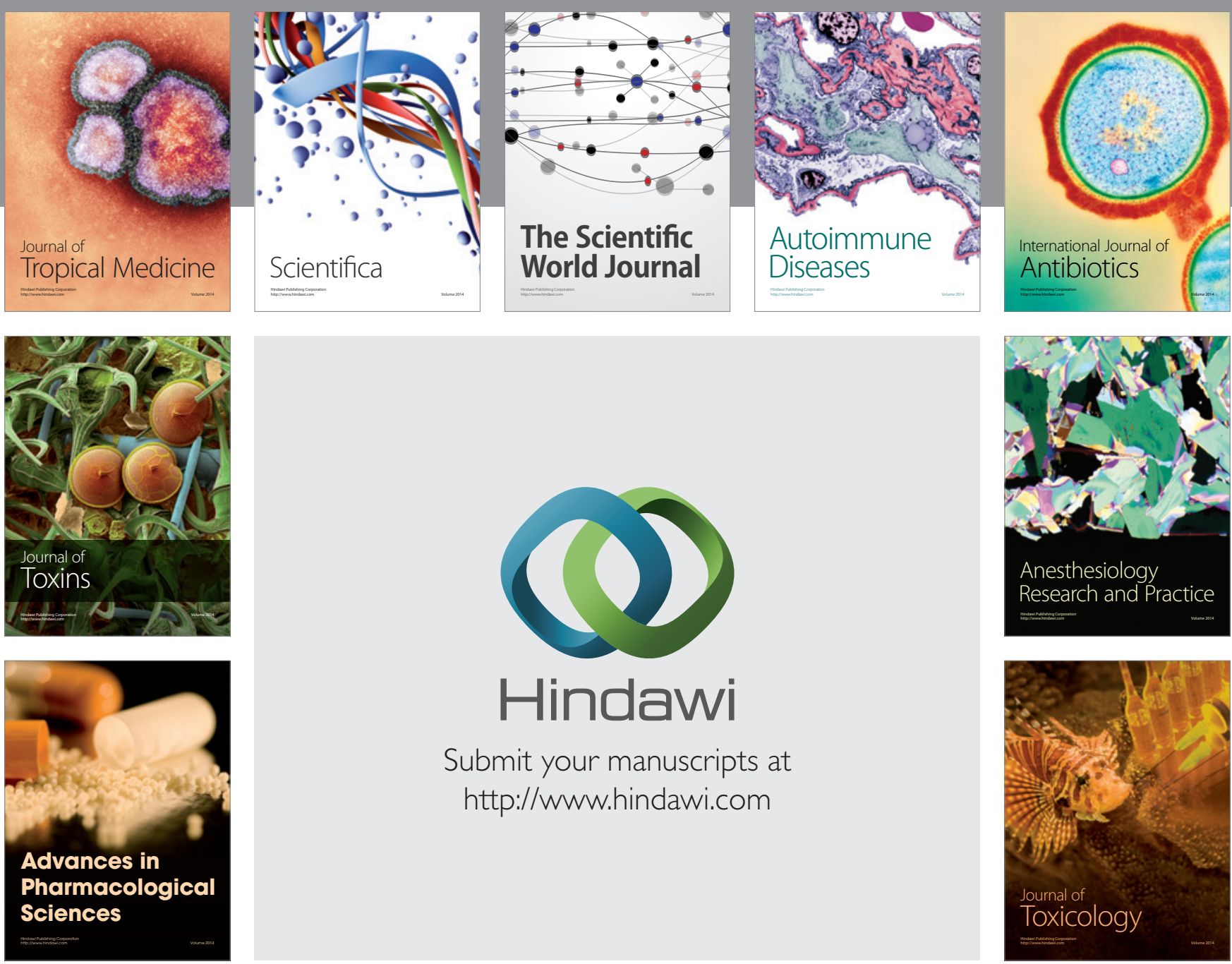

\section{Hindawi}

Submit your manuscripts at

http://www.hindawi.com
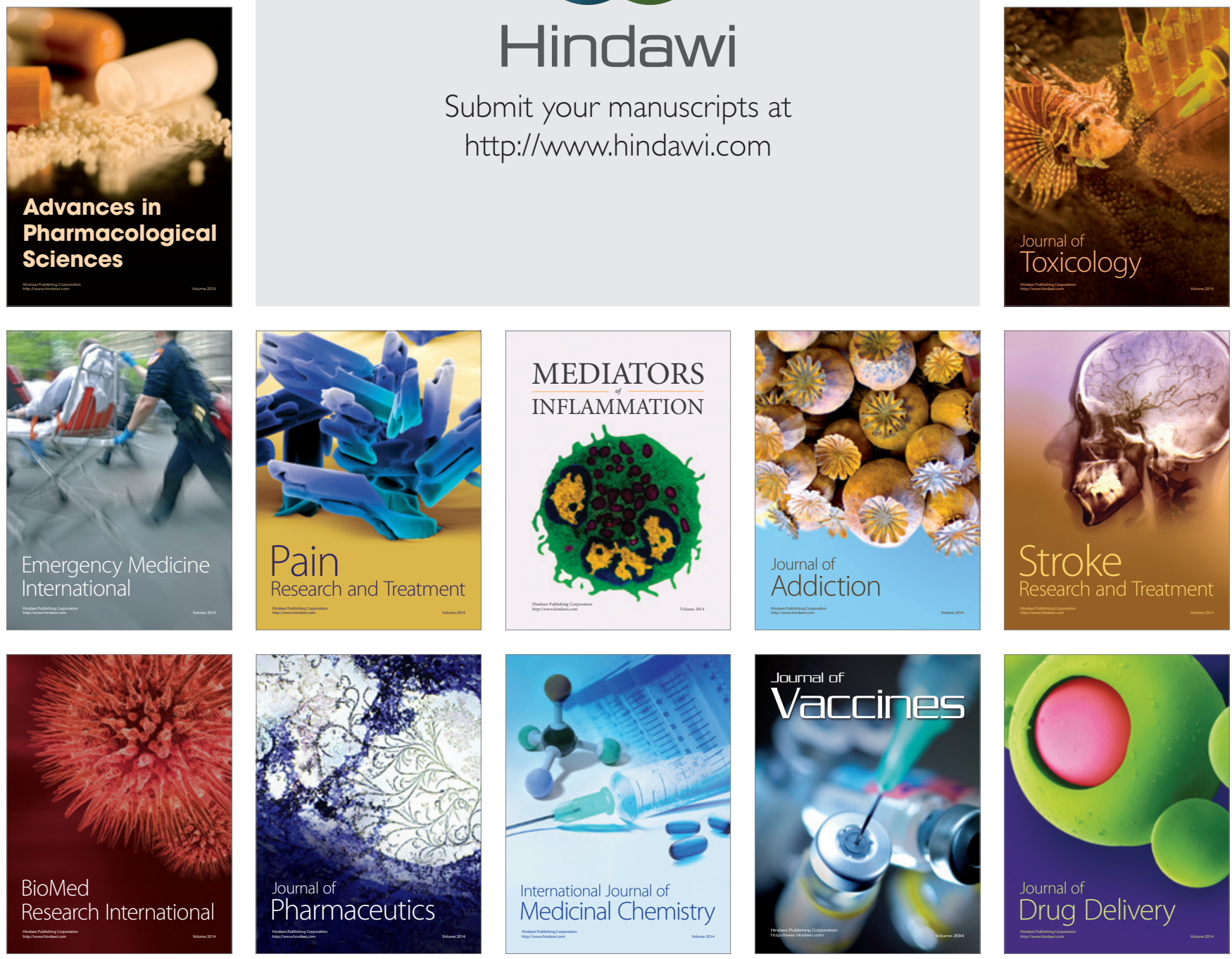